\title{
Noun Phrase in Mandailing Language
}

\author{
Azizah Husda $^{1^{*}}$ and Mulyadi $^{2}$ \\ ${ }^{1}$ English Department, Faculty of Teacher Training and Education, Universitas Prima \\ Indonesia, Medan, Indonesia \\ ${ }^{2}$ Linguistics Department, Faculty of Arts, Universitas Sumatera Utara \\ Medan, Indonesia \\ E-mail: azizahhusda@unprimdn.ac.id;mulyadi@usu.ac.id \\ *Corresponding author details: Azizah Husda; azizahhusda@unprim.dn.ac.id
}

\begin{abstract}
This paper discusses on the rules of Noun Phrase (NP) in Mandailing language. The objectives are firstly to structurally examine the phrase structure rules (PSR) of NP in Mandailing language and to investigate the constituents of each rules in NP. The method is descriptive qualitative with a case study. The data taken from the native speakers of Mandailing language through interviewing. The data are the utterances of Mandailing language in daily conversation. The analysis is based on the use of X-Bar theory, to see how NPs in Mandailing language are hierarchically governed and presented in tree diagram. Thus, the findings showed that there are five major rules of NP in Mandailing language, (a) single noun as headword, (b) pre-modifier preceedes head noun, (c) post-modifiers follows head noun, (d) head noun between pre-modifier and post-modifier, and (e) complex NP with coordinative conjunction. Also, there is found particle na to relate NP with the complement such as AP. To summarize, Mandailing language has similar patterns of word order with Indonesia language. Overall, this research gives contribution to provide a deep understanding in studying morphosyntactic in linguistics especially phrase structures beyond the effort on exploring and revitalizing a regional language in Indonesia.
\end{abstract}

Keywords: phrase; noun phrase; mandailing language

\section{INTRODUCTION}

Sentence is formed by several clauses whereas clauses are formed by some phrases or words. The phrases and words fill in the functions in the sentence in the form of subject $(\mathrm{S})$, predicate (P), object (O) and complement (C). The presence of phrases in a sentence is very crucial because phrase may clarify words to be more specific and able to reduce the scope of words and meanings. [1].

The term of phrase is often defined as a group of words. The phrase is also defined as grammatical unit in the form of combination of non-predictive words or it is commonly called word combination which fills one of the syntactic functions in a sentence [2]. [3] state that a phrase is a grammatical unit which consists of one or more words, not exceeded by the limits of the elemental clause functions and has a headword to determine the lexical category.

This research focuses on the structures of noun phrase in Mandailing language. The researcher formulates the problem to investigate the noun phrases in Mandailing language by presenting tree diagrams to describe the hierarchical structures in making up the phrases. In language variety, Mandailing language has the same position with other regional languages existed in Indonesia. It has some functions such as (a) being used dominantly as a language in its region, used at schools especially in remote areas, (b) as a symbol of ethnicity and is used as a means of communication in any association, and (c) an interface among families and communities especially the speakers of Mandailing language.

Conducting the research, there are some contributions (a) to provide a broad and deep knowledge in understanding syntax, phrase structures ordered in a sentence and (b) regional language may give valuable understanding of language vocabulary in Indonesia and linguistic development in universal.

Beginning with noun phrase, at least it consists a single word as the head to label the lexical category.[4] Noun phrase is often termed as nominals because every single noun phrase (NP) like the other phrases should have a head and nominals can be the head of an NP [5], [6].

A simple noun phrase can consist of just one word, which is normally a noun, although pronouns can replace nouns, and adjectives occasionally stand in for nouns. [7]-[10]. A determiner is also usually required. While a noun or pronoun can sometimes stand alone as a singleword, simple noun phrase, a determiner such as the article (a, the etc) cannot stand alone and is defined by its function in relation to the item it determines. The noun or pronoun is therefore regarded as the head of the noun phrase [11]. 
A complex noun phrase contains the obligatory head (a word that could stand alone as a simple noun phrase) as well as modification provided by a determiner (det), a premodifier (premod) and a post-modifier (postmod)[12], [13]. Pre-modifiers occur before the head, whereas postmodifiers come after the head. Pre-modifiers are often adjectives, but other nouns can also modify the head, and when this occurs, the premodifying noun may be accompanied by a premodifying adjective. Post-modifiers can consist of relative clauses, non-finite clauses, prepositional phrases, adverbs, adjectives and noun phrases in apposition. While the premod of the head are of two main types: determiners and modifiers; the postmod of the head are of three types: complements, modifiers, and peripheral elements [14].

In order to identify the NPs as the objects of this research, phrase structure rules is the way to begin the analysis of constructing NPs. [15]. From the brief explanation previously, every word may belong to lexical category. Then, lexical category forms headword of any phrases. In knowing how the phrases are formed or governed, PSR is used as the approach, [16] because in using PSR, NP can be made up by a noun as its headword of each constituent. NP itself may functions either as subject, object or complement in a sentence, [17].

In analyzing the structures of NP, the researchers used XBar theory which is to draw the structures hierarchically in government and binding.[14], [18]-[21] Let's see the following example. I dia di tabusi ho baju mi? (Where did you buy your shirt? /Di mana kamu membeli bajumu). From the example, there are two NPs identified such as ho (you) and baju mi (your shirt). Both have different structures of NPs which are described in the following diagram.

(1.a)<smiles>N[15NH]N[12NH]</smiles>

(1.b) NP ho

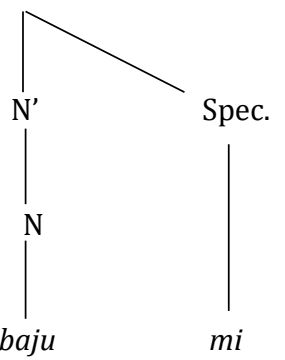

FIGURE 1: Tree Diagram of NPs

The two diagrams presented are slightly different because in the constituents, they have also different structures. The PSR of both NPs are:

$$
\begin{aligned}
& \mathrm{NP} \longrightarrow \mathrm{N}^{\prime} \\
& \mathrm{NP} \longrightarrow \mathrm{N}^{\prime} ; \text { Spec. }
\end{aligned}
$$

Those PSR show that (1.a) has the pronoun ho (you) as its headword. In the sentence, it functions as the subject while (1.b) has the noun baju (shirt) and post-modifier (mi).
The post-modifier provides the genitive pronoun or the specifier mi (your) which functions as specifier with the same position with determiner. Those rules have also happened with Indonesian language which the sentence pattern is (modified-modifier) rather than English (modifier-modified) like saying gadis cantik with beautiful girl.

\section{METHOD}

This paper applies on descriptive qualitative approach with a single case study design. As [22] stated that a case study enables a researcher to closely examine the data within a specific context. In most cases, a case study method selects a small geographical area or a very limited number of individuals as the subjects of study. Case studies, in their true essence, explore and case study as a research method to investigate contemporary real-life phenomenon through detailed contextual analysis of a limited number of events or conditions, and their relationships. Thus, this research takes a case by describing the structures of NP in Mandailing language.

$\mathrm{X}$-Bar theory is used as the literature to analyze the data of NPs while the data were taken by having some native speakers as the participants of the study through interviewing. Right after that, the data were encrypted as well to draw the findings of the problems of research.

\section{Findings and Discussions}

Speaking of PSR, it has sort of rules with the pattern of where $\mathrm{X} \rightarrow \mathrm{YZ}$. This rule says to take the node $\mathrm{X}$ and expand it into the nodes $Y$ and $Z$. Alternatively, going from right to left, it would notice that $Y$ and $Z$ next to each other, it could combine both to create X. PSR can be categorial i.e. rules that expand categories into other categories, or they can also be lexical i.e. rules that expand category labels by word (lexical items). So, from the data collection, it can be found that NP in Mandailing language has some structure rules such as the following table:

TABLE 1: Structure Rules of NP

\begin{tabular}{|l|l|}
\hline No. & Structure Rules \\
\hline 1. & $\mathrm{NP} \rightarrow \mathrm{N}$ (headword) \\
\hline 2. & $\mathrm{NP} \rightarrow$ Pre-modifier $+\mathrm{N}$ \\
\hline 3. & $\mathrm{NP} \rightarrow \mathrm{N}+$ Post-modifier \\
\hline 4. & $\mathrm{NP} \rightarrow$ Pre-modifier + N + Post-modifier \\
\hline 5. & $\mathrm{NP} \rightarrow \mathrm{NP}+\mathrm{C}+\mathrm{NP}$ \\
\hline
\end{tabular}

As it was previously defined that a phrase may consist of a single word of a noun as its headword in NP. If it is a noun as the headword, so it is called as NP. This argument may reject that a phrase should only consist of more than a word inside. Before analyzing every rule of NP in Mandailing language, researchers underline that Mandailing has the same pattern of Indonesian structures in forming up sentences (ModifiedModify), it is different with English (Modify-Modified) because Mandailing is a regional language which is influenced by Bahasa. Simply, it begins with the headword to label the phrase and modifiers followed by right after.

In the first rule, NP in Mandailing language could stand by its noun as headword. Look at the example below:

I dia (dimana/where) ho (anda/you) sikolah(sekolah/school)?

(Dimana anda sekolah? Where do you school?) The sentence points that there are two NP which has a single word as the headword. They are ho (anda/you) and sikolah (sekolah/school). 
So, the representation of the tree diagrams would be:

(2.a)

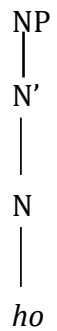

(2.b)<smiles>[Nb]NNN=[Nb]</smiles>

FIGURE 2: Single Nouns in NPs

Previously, in the first rule proves that it consists of a single word as its head. Then, in this second rule that NP could consists of more than a single word. It may contain one or more pre-modifiers which precede the noun as its head.

\section{Adong (ada/there is) sada(seunit/a) bagas (rumah/house) di topi (di tepi/in the) pante (pantai/seashore) \\ (Ada seunit rumah di tepi pantai/There is a house in the seashore)}

By showing the sentence, the NP which contains $\mathrm{N}$ bagas and preceded by pre-modifier is sada as the specifier to label sada bagas (sebuah rumah). See (Figure 3).
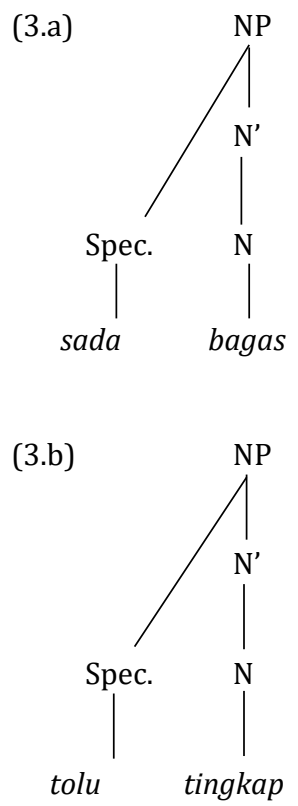

FIGURE 3: Pre-Modifiers in NPs

This section by presenting the rule which is opposite to the section of noun preceded by pre-modifiers. Still, a NP should have a noun as its head. Furthermore, if the NP has more elements than its head, it is a complement either one or more pre-modifiers (precedes a noun) and/or one or more post-modifiers (modifiers which follow the head). Clearly, it can be seen by having the following table.
TABLE 2: Forms of Post-Modifier

\begin{tabular}{|c|c|c|c|}
\hline No. & $\begin{array}{l}\text { Forms of } \\
\text { Post- } \\
\text { Modifier }\end{array}$ & Examples & Meaning \\
\hline 1. & Determiner & $\begin{array}{l}\text { Bayo i } \\
\text { dompak } \\
\text { manajak di } \\
\text { saba }\end{array}$ & $\begin{array}{l}\text { The man is } \\
\text { hoeing in the rice } \\
\text { field (Pria itu } \\
\text { sedang } \\
\text { mencangkul di } \\
\text { sawah) }\end{array}$ \\
\hline 2. & $\begin{array}{l}\text { Adjective } \\
\text { Phrase }\end{array}$ & $\begin{array}{l}\text { Guru na } \\
\text { mokmok i } \\
\text { dompak } \\
\text { mangajar } \\
\text { saro inggoris }\end{array}$ & $\begin{array}{l}\text { The fat teacher } \\
\text { is teaching } \\
\text { English (Guru } \\
\text { yang gemuk itu } \\
\text { sedang mengajar } \\
\text { bahasa Inggris) }\end{array}$ \\
\hline 3. & $\begin{array}{l}\text { Demonstra- } \\
\text { tive } \\
\text { Pronoun } \\
\end{array}$ & $\begin{array}{l}\text { Pinggan i } \\
\text { matapor }\end{array}$ & $\begin{array}{l}\text { The plate broke } \\
\text { (Piring itu } \\
\text { pecah) }\end{array}$ \\
\hline 4. & Genitive NP & $\begin{array}{l}\text { Hata hata ni } \\
\text { si Sangkot } \\
\text { lambok } \\
\text { malidung } \\
\text { binege }\end{array}$ & $\begin{array}{l}\text { Sangkot's } \\
\text { words are gently } \\
\text { heard. (Kata- } \\
\text { katanya si } \\
\text { Sangkot lemah } \\
\text { lembut didengar) }\end{array}$ \\
\hline 5. & $\begin{array}{l}\text { Genitive } \\
\text { Pronoun }\end{array}$ & $\begin{array}{l}\text { Angkang ku } \\
\text { sada halak } \\
\text { pasobar }\end{array}$ & $\begin{array}{l}\text { My brother is an } \\
\text { indulgent man } \\
\text { (Abangku } \\
\text { adalah orang } \\
\text { yang sabar) }\end{array}$ \\
\hline 6. & $\begin{array}{l}\text { Prepositio- } \\
\text { nal Phrase }\end{array}$ & $\begin{array}{l}\text { Baju na di } \\
\text { lamari i } \\
\text { marrerakan }\end{array}$ & $\begin{array}{l}\text { The clothes in } \\
\text { the closet are } \\
\text { scattered. (Baju- } \\
\text { baju di lemari } \\
\text { itu berserakan) }\end{array}$ \\
\hline
\end{tabular}

Let's take two representatives to present the tree diagrams of which NP is followed by post-modifiers as the complements. In this case, take no. 1 and 2 to identify the structures.

(4.a)

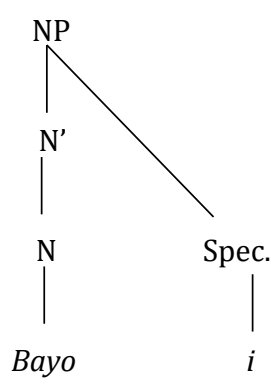

(4.b)

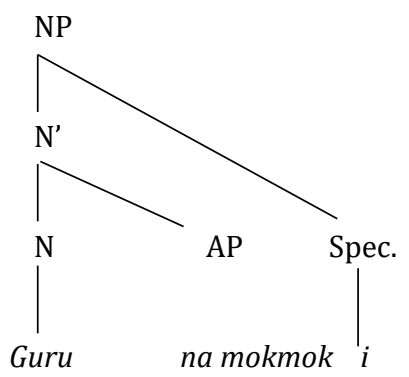

FIGURE 4: Post-modifiers in NPs

Both figures above have a different form of post-modifiers as the specifier. They illustrate different structures of NP. Figure 4.a, the noun is followed by the specifier to show the entity of the man (bayo i). Also, figure 4.b, the noun followed by the spesifier $i$ like figure 4.b but it is preceded by Adjective Phrase (AP) as the complement with the head of adjective from the word na mokmok which means fat. 
In Mandailing language, there is particle $n a$ to label the adjective word before it modifies the noun in NP. So, if there is no particle $n a$ attached to, obviously it is meaningless or it has different meaning.

By showing table 2 previously, the variety of post-modifiers as a complement that appears following the noun as the main element in the NP as well as providing an explanation for the section of which the NP may consists of both premodifiers and post-modifiers at once. To clarify, here are the examples.

\section{(a) Inda adong karosi na rara di bagasan kalas}

(Tidak ada kursi merah di dalam kelas/There is no red chair in the class)

\section{(b) Deba baju sikolah di lamari i marerakan}

(Beberapa seragam sekolah di dalam lemari ini berserakan/Some clothes in the closet are scattered).

Those sentences succcesfully investigate the use of two modifiers namely premodifiers and postmodifiers. Those give complete structures of NP in each sentence. Consider the bold and see the configuration of the structures in these given diagrams.

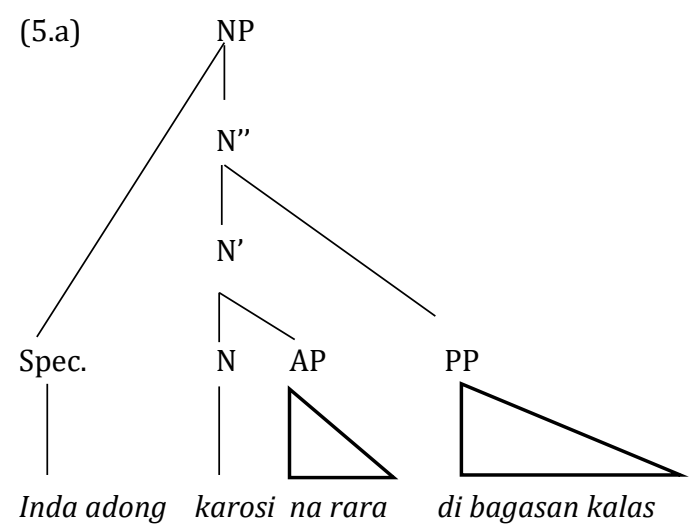

In the figure 5.a, there is a negative form of pre-modifier inda adong (tidak ada) which is identified as the specifier. Also, there are two prost-modifiers, AP and PP as the complements of NP karosi (kursi) but there is a slightly difference of the representation of $\mathrm{NP}$ in the second example, (See Figure 5.b).

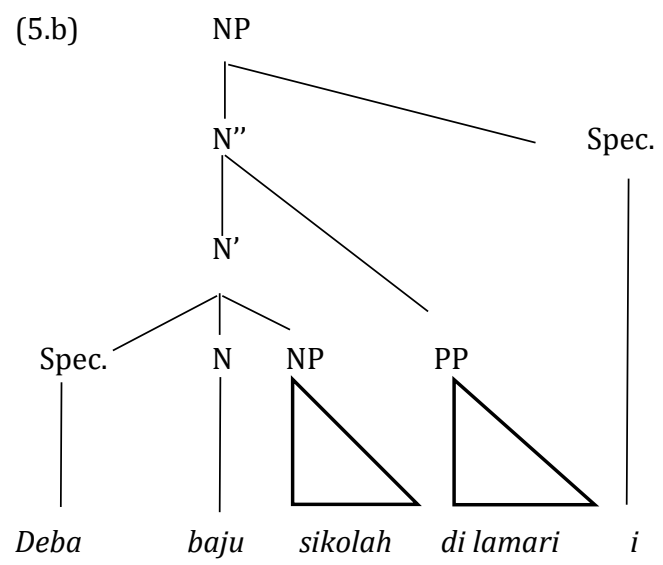

FIGURE 5: $\mathrm{a}, \mathrm{b}$ Pre and Post-Modifiers

The simple pre-modifier above in figure 5,ba contains a specifier that is negative inda adong. Then, the AP as the post-modifier or complement followed the head noun in NP and also added by another complement, that is PP. Meanwhile, comparing with the figure 5.b where it has more complex structure of NP. The figure looks more different for presenting the specifiers and their positions because the first one is deba (beberapa) as the quantifier and the other is $i_{(i t u)}$ as the article. Besides, in figure 5.b, it has two complements; NP and PP. Remember that PP may consist of a preposition and a noun phrase such in figure 5.b.

On the principle of NPs, it is possible to repeat NPs indefinitely. NPs are joined by coordinating conjunctions such as and, or. Let's see the simple NPs contains coordinative conjunction.

\section{Pitu partolot dohot sada lor}

(Tujuh pensil dan satu penggaris /Seven pencils and a ruler)

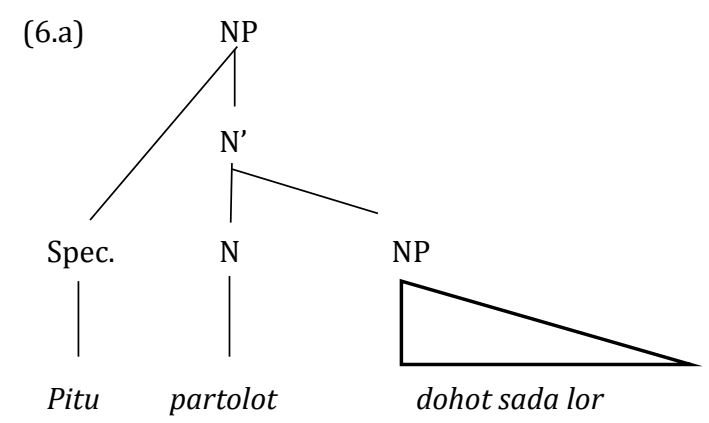

FIGURE 2: NPs with Coordination

Coordination may bring out the positions of NPs as the bridge to separate the first NP and second NP. Coordination should be used at the same level constructions or in the compound sentences. So, it means if the first NP and the second one is called NPs complex. In detail, the second NP is separated with the use of coordination dohot which means "and", thus the presentation of the second NP is:

(6.b)

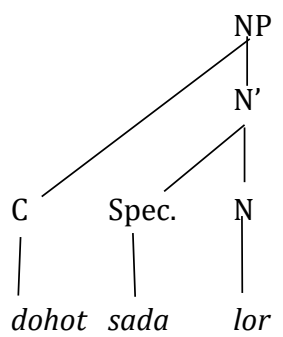

The figure 6.b draws that there are pre-modifiers such as coordinative conjunction and numeral specifier as the continuity of the figure 6.a.

\section{CONCLUSION}

Discussing the structures of NP in this research may give some conclusions and contributions the object, Mandailing language. First, there are some rules of NPs structure rules and each rules has different structures where the PSR of Mandailing language is generally divided into five major categories, namely (a) single NP, N as its headword; (b) Pre-modifier followed by the head N; (c) Noun as its head followed by post-modifier; (d) Head noun is between premodifier and post-modifier; and (e) Complex NPs with coordinative conjunction in between. Thus, those rules are used to examine hierarchically the structures and presented into the tree diagrams with X-Bar theory by generating from the minimum units to the maximum projections of NPs.

Second, in fact, the PSR of NPs in Mandailing language has similar rules with Indonesian language, not only because Mandailing is the part of regional languages in Indonesia but the patterns of word order is matched to Indonesian language, that is D-M like Indonesian language and adopts some words as loan words rather than English. 
There is also a unique thing found in Mandailing language, the use of particle na found in AP as clitic to integrate NP with the complement AP. The occurrence of the particle na raises up a big question to the study of morphosyntax has more than one topic that can be widely discussed and the topics are integrated to each other.

Overall, this research is quite challenging to do because this research brings out a language phenomenon in morphosyntax to open up the linguistics study in regional languages beyond Indonesia through searching for diversity and as the language maintenance to revitalize any particular languages and cultures.

\section{REFERENCES}

[1] V. Fromkin, R. Rodman, and N. Hyams, "Syntax: The Sentence Patterns of Language," An Introd. to Lang., pp. 117-178, 2011.

[2] N. Hadi, "Bahasa Indonesia," Religia, no. 6, p. 203, 2019, doi: 10.28918/religia. v22i2.2068.

[3] G. P. Delahunty and J. J. Garvey, The English Language: From Sound to Sense. 2010.

[4] K. Börjars, K. Burridge, K. Börjars, and K. Burridge, "The noun phrase," in Introducing English Grammar, 2019.

[5] A. D. Andrews, "The major functions of the noun phrase," in Language Typology and Syntactic Description Second Edition: Volume 1: Clause Structure, 2007.

[6] E. Keizer, The English Noun Phrase. 2007.

[7] A. Kornai, "The internal structure of Noun Phrases," Approaches to Hungarian, vol. 1, pp. 79-92, 1985, [Online].

Available:https://pdfs.semanticscholar.org/c91c/4 7b18e529149705bc14348bd07e70f225977.pdf.

[8] G. L. Murphy, "Noun phrase interpretation and conceptual combination," J. Mem. Lang., 1990, doi 10.1016/0749-596X (90)90001-G.

[9] E. L. Keenan and B. Comrie, "Noun Phrase Accessibility and Universal Grammar," Linguist. Inq., 1977.
[10] S. P. Abney, "The English Noun Phrase in its Sentential Aspect," RLE Prog. Rep., no. 130, p. 234 p., 1987, [Online].

Available:http://cat.inist.fr/?aModele=afficheN\&cpsi $\mathrm{dt}=11923795$.

[11] L. L. S. Cheng and R. Sybesma, "Bare and not-so-bare nouns and the structure of NP," Linguist. Inq., 1999, doi: 10.1162/002438999554192.

[12] M. S. Dryer, "Noun phrase structure," in Language Typology and Syntactic Description, Second Edition: Volume II: Complex Constructions, Cambridge University Press, 2007, pp. 151-205.

[13] P. C. Gordon, R. Hendrick, and M. Johnson, "Effects of noun phrase type on sentence complexity," J. Mem. Lang., 2004, doi: 10.1016/j.jml.2004.02.003.

[14] A. Carnie, “Drawing X-bar Trees,” 2006.

[15] D. Georgi and G. Müller, "Noun-phrase structure by reprojection," Syntax, 2010, doi: 10.1111/j.14679612.2009.00132. x.

[16] J. Butler, "Phase structure, Phrase structure, and Quantificatio," Science (80-.)., no. May, 2004.

[17] S. Pinker, "Phrase Structure Rules:" Lang. Learn. Lang. Dev. With New Comment. by Author, pp. 96-165, 2019, doi: $10.2307 / j$. ctvjsf414.8.

[18] W. Sun, "X-bar Theory," 2015.

[19] G. Webelhuth, "X-bar Theory and Case Theory," Gov. Bind. Theory Minimalist Progr., vol. 6, pp. 15-96, 1995.

[20] J. Kim and P. Sells, "English Syntax: An Introduction of Language," p. 384, 2008.

[21] M. Mulyadi, "Frase Preposisi Bahasa Indonesia: Analisis X Bar," Kaji. Sastra, vol. 34, no. 1, pp. 1-12, 2010.

[22] M. Bolder-Boos, "Der Krieg und die Liebe Untersuchungen zur römischen Venus," Klio, vol. 97, no. 1, pp. 81-134, 2015, doi: 10.1515/klio-2015-0004. 